\title{
Microcytic anemia with liver iron overload
}

INSERM

\section{Source}

INSERM. (1999). Orphanet: an online rare disease and orphan drug data base. Microcytic anemia with liver iron overload. ORPHA:83642

Congenital hypochromic microcytic anemia with progressive liver iron overload paradoxically associated with normal to moderately elevated serum ferritin levels has been described in three unrelated patients. 